\title{
Developments of Project Based Learning Textbooks to Improve Emotional Intelligence of Students in Five Grade in Elementary Schools
}

\author{
Dwi Yulia Sari .AY ${ }^{1 *}$, Rochmiyati ${ }^{2}$, A. Ambarita ${ }^{3}$ \\ $\left\{\right.$ *dwiyuliasay@gmail.com ${ }^{1}$, rochmiyatiazwardi@yahoo.co.id ${ }^{2}$, Alben_ambarita57@yahoo.com $\left.{ }^{3}\right\}$ \\ Master of Teaching Primary Education, FKIP Lampung University, Indonesia ${ }^{1}$, Department of Primary \\ School Teacher Education, FKIP Lampung University, Indonesia ${ }^{2}$, Department of Primary School \\ Teacher Education, FKIP Lampung University, Indonesia ${ }^{3}$
}

\begin{abstract}
This study aimed to developments of project based learning textbooks to improve emotional intelligence of students in five frade in elementary schools. The design of this research was adopted from Borg \& Gall design model. The subject were 50 students divided into experiment and control class with purposive sampling technique. The data collection was done by emotional intelligence questionnaires, eligibility questionnaires, interviews and observations. The effectiveness of textbook shown from students emotional intelligence in experiment class $\mathrm{N}$-gain $(63 \%)$ with medium category which was higher than control class (34\%) with low category. The feasibility of textbooks was assessed by material expert with "very valid", media expert with "very complete", and media linguist with "usable" category.
\end{abstract}

Keywords: Project Based Learning (PjBL), Students Emotional Intelligence, Textbooks

\section{Introduction}

The $21^{\text {st }}$ century requires every individual to have qualified hard and soft skills to be able to enter the workforce and be ready to compete. Three skills that need to be provided to every individual in the $21^{\text {st }}$ century, one of which is learning and innovation skills. Learning and innovation skills consist of four aspects, namely creativity and innovation, critical thinking and problemsolving, communication, and collaboration [1]. Basically, the implementation of creative and innovative skills, critical thinking and problem solving, communicative and collaborative not only involves intellectual intelligence but also emotional intelligence. Emotional intelligence provides opportunities for individuals to exploit their intellectual potential. Emotions connect the body with the brain and provide energy to accelerate academic achievement, health and personal success. Everything humans do is controlled by emotions [2]. Emotional intelligence is meta-ability, which determines how well we are able to use the other skills we have, including intellectuals that have notbeen honed [3].Emotional intelligence is a type of social intelligence that involves the ability to monitor ones own and others feeling, to distinguish between them, and to use the information to guide thinking skill and actions. The scope of emotional intelligence includes verbal and nonverbal judgment and emotional expression, emotional regulation in theirself, and the use of emotional content in problem solving [4]. Emotional intelligence enhances the ability to learn and solve problems. People with a higher EI are able to generate a mood that allows them to do better on challenging cognitive tasks [5].

Emotional intelligence can be learned and increased with age, but with a note there must be motivation, habituation, feedback, and efforts to improve the skills of the individual itself. The truth is that some will be more naturally gifted than others but the good news is that emotional intelligence skills can be learned. (This must be so because emotional intelligence is 
shown to increase with age) [6]. The importance of teaching emotional intelligence to children to provide better opportunities for them in order to exploit the potential they have [3]. The process of education and care are gained by children, forming learning experiences that are meaning ful to him. Besides family, school als o plays a big role in the development of a childs emotional intelligence. Especially, considering the child spent a long time at school and performvarious activities that might affect the formation of emotional intelligence. In fact the emotional intelligence of students is not well developed. This can be known from the results of preliminary res earch. The preliminary res earch was conducted by giving a questionnaire of emotional intelligence that researchers had developed to 394 of five grade elementary schools students who had implemented the 2013 curriculum in the District of Rajabasa, Bandar Lampung. The results have shown at Table 1.

Table 1. Average Score ofEmotional Intelligence of Five Grade Elementary School Student In Academic Year 2019/2020 of Rajabasa, Bandar Lampung.

\begin{tabular}{|c|c|c|c|c|c|}
\hline No & School Name & Class & $\begin{array}{l}\text { Number of } \\
\text { Student }\end{array}$ & $\begin{array}{c}\text { Average Score of Emotional } \\
\text { Intelligence }\end{array}$ & Category \\
\hline \multirow{3}{*}{1} & \multirow{3}{*}{ SDN 1 Rajabasa } & $\overline{\mathrm{VA}}$ & 30 & 113 & Medium \\
\hline & & VB & 25 & 108 & Low \\
\hline & & $\mathrm{VC}$ & 17 & 110 & Low \\
\hline \multirow{3}{*}{2} & \multirow{3}{*}{ SDN 2 Rajabasa } & VA & 30 & 110 & Low \\
\hline & & VB & 51 & 113 & Medium \\
\hline & & $\mathrm{VC}$ & 55 & 108 & Low \\
\hline \multirow{2}{*}{3} & \multirow{2}{*}{ SDN 3 Rajabasa } & VA & 25 & 107 & Low \\
\hline & & VB & 27 & 112 & Medium \\
\hline 4 & SDN 3 Rajabasa Jaya & $\mathrm{V}$ & 36 & 111 & Medium \\
\hline \multirow{3}{*}{5} & \multirow{3}{*}{ SDN 1 Rajabasa Raya } & $\overline{V A}$ & 33 & 108 & Low \\
\hline & & $\overline{V B}$ & 32 & 113 & Medium \\
\hline & & $\mathrm{VC}$ & 33 & 111 & Medium \\
\hline & Sum & & 394 & 1324 & \\
\hline & Average & & & 110 & Low \\
\hline
\end{tabular}

Based on the measurement results, it shown that the average value of emotional intelligence of students is 110, and have "low" category. Development of emotional intelligence of these students becomes "homework" educators. Educators as the spearhead of education must be able to maximize it with a variety of tips that are considered to provide maximum results for increasing students emotional intelligence. Therefore, it seems ess ential to consider opportunities for emotional engagement and development in educational settings, where the principal aims is to prepare youth (in the case of higher education) not only for academic and professional success but als o for a satisfying and enjoyable profes sional and private life [7]. The increasing of emotional intelligence in schools related to the learning process undertaken. Emotional intelligence can be taught explicitly or implicitly. If emotional intelligence is taughtimplicitly, it does not add learning material directly but educators only need to determine approaches, strategies and learning models that use aspects of emotional intelligence.

Learning models are as a frame of approaches, strategies, methods, and learning techniques. There are several learning models suggested in the curriculum of 2013, one of which is the project-based learning. One of definition says that project-based learning (PjBL) is an approach that engages students in inquiry and all related activity. This method is structured based on the some questions which was answered by students when participate of 
assignments [8]. The characteris tics of project-based learning are elaborate students thinking skills, enable the students have to creativity, make the students work together and train them to access the information. Project-based learning requires the students to participate in the learning activities especially teamwork [9]. The basic of project-based learning allows students to use and improve their emotional intelligence. The experience of project-based learning also involves students in communication with others which gives them the opportunity for debriefing and re-application, which in support of developing self-awareness and generating active participation and increased motivation [7].

Based on this, it is needed project based learning based learning through the development of appropriate and appropriate learning resources so that students' emotional intelligence can be increased. One example of a learning resource that can be developed is a textbooks. Basically, textbooks are mostly used teaching and learning materials for teachers and the students. They not only provide a framework for teachers to achieve the purpose, but als o have function as a guide to teaching [10]. Textbooks are books that used as a standard source of information for formal learning of a subject and instruments for teaching and learning which must be considered as one of the many sources that could be taken by teachers fot creating effective les sons and could be offer a framework of guidance and orientation [11]. Textbooks have an important role in the teaching and learning process and they are the main agents in conveying knowledge to students. In addition, another function of the textbook is to provide knowledge to students easily and organizely [10].

Based on the background above, the authors will conduct research to produce products in the form of developing textbooks based on project based learning models. The aim is to improve the emotional intelligence of elementary s chool students, especially grade five at SDN 3 Rajabasa, Rajabasa District.

\section{Method}

This type of research was research and development research (R\&D) which is used to develop and validate educational products. The term "product" includes not only material objects, such as textbooks, in structional films, etc, but also intended to refer to procedures and processes, such as teaching methods or method for organizing teaching [12]. The steps in this research refer to Borg and Gall.

The population in this study were all five grade students of state elementary schools in Rajabasa who had implemented the 2013 curriculum with 394 students in academic year 2019/2020. The sampling technique in this study used a purposive s ampling technique, so that the experiment class (using the development of textbooks based on project based learning) in this study 25 students in SDN 3 Rajabasa, and 25 students in SDN 1 Rajabasa as a control class (did not use textbooks based on project based learning). Data collection techniques used the scale of emotional intelligence thathas been tested for validity and reliability to measure the intelligence of students, questionnaires for learning the feasibility of products, and interviews and observations to find out the res ponses of educators and students. Data analysis techniques were carried out quantitatively andqualitatively. The study in this article discussed the feasibility and effectiveness of project-based textbooks to improve student intelligence.

The feasibility of textbooks was assessed by material experts, media experts, linguists, using ins truments in the formof questionnaires. Data obtained through the expert validation sheet consists of quantitative data based on the results of the score on the approval of the suitability of the textbook and qualitative data obtained based on comments or suggestions 
regarding the feasibility of the teaching being developed.The requested or expected score of each component could be calculated using the following formula (1).

$$
\text { (1) } \quad \mathrm{N}=\frac{\mathrm{R}}{\mathrm{SM}} \mathrm{X} 100 \%
$$

Information:

$\mathrm{N} \quad=$ value sought or expected

$\mathrm{R} \quad=$ raw score obtained

$\mathrm{SM} \quad=$ maximum score

The result of as sess ment of material experts , media expert media linguist, and practitioners were converted to the final score which can be seen in Table 2.

Table 2.Validity Criteria for Material Experts, Media Experts, Linguists, and Practitioners

\begin{tabular}{cr}
\hline Final Score & Criteria \\
\hline $81 \%-100 \%$ & Very Valid, very complete, can be used \\
\hline $61 \%-80 \%$ & Valid enough, effective enough, can be used with minor improvements \\
\hline $41 \%-60 \%$ & Less valid, less effective, less thorough, not for use \\
\hline $21 \%-40 \%$ & Invalid, ineffective, incomplete, cannot be used \\
\hline $0 \%-20 \%$ & Very invalid, very ineffective, very incomplete, cannot be used \\
\hline
\end{tabular}

Next is testing the effectiveness of textbooks. First, analyzing students pretest and posttest score with the emotional intelligence questionnaire as a measurement tool. The emotional intelligence questionnaire contain 55 items and has been tested for validity and reliability. Alternativeanswers in this questionnaire use a Likert scale, with four choices that could be seen in the following table.

Table 3.Guidelines the Scoring Intelligence Emotional Questionnaire

\begin{tabular}{ccccc}
\hline Rating Standards & Always & Often & Rarely & Sometimes \\
\hline Favorable statement & 4 & 3 & 2 & 1 \\
\hline Unfavorable Statement & 1 & 2 & 3 & 4 \\
\hline
\end{tabular}

After obtaining students emotional intelligence score, then testing the effectiveness of the textbook using paired sampel t-test techniques, gain analysis, and independent t-test. The purpose of paired sample t-test is to compare the difference average pretest and posttests data from the experimental class and control class. The basic for decision making is as follows

a. If $t_{\text {value }}>t_{\text {table }}$ and probability (Asymp Sig) $<0,05$, then there are differences in emotional intelligence of student before and after carrying out learning in experiment class and control class.

b. If $t_{\text {value }}<t_{\text {table }}$ and probability (Asymp Sig) $>0,05$, then there is no differences in emotional intelligence of student before and after carrying out learning in experiment class and control class [7]. 
Hake revealed that in order to know the effectiveness of a learning in conceptual understanding, an analys is of the average value of normalized gain was carried out. The $n$ Gain formula according to Meltzar is as follows.

$$
\text { (2) } \mathrm{N}-\text { gain }=\frac{\text { posttest score-pretest score }}{\text { maximum score-pretest score }}
$$

The result of the $\mathrm{N}$-gain calculation were interpreted using the clas sification (Table 4).

Table 4. N-Gain Clasification

\begin{tabular}{cc}
\hline Value of N-gain & Interpretation \\
\hline $\mathrm{N}-$ gain $>0,7$ & High \\
\hline $0,3<\mathrm{N}-$ gain $\leq 0,7$ & Medium \\
\hline $\mathrm{N}-$ gain $\leq 0,3$ & Low \\
\hline
\end{tabular}

The result of the calculation of emotional intelligence in experiment class and control class could be interpreted by using theinterpretation category of the effectiveness of $\mathrm{N}$-gain have shown Table 5.

Table 5. Classification the Effectiveness of Textbooks

\begin{tabular}{cc}
\hline Percentage $(\%)$ & Interpretation \\
\hline$<40$ & Ineffective \\
\hline $40-55$ & Less Effective \\
\hline $56-75$ & Effective Enough \\
\hline$>76$ & Efective \\
\hline
\end{tabular}

Independent t-test used to discover the difference using textbooks that developed in grade $\mathrm{V}$ elementary school students who have implemented the 2013 curriculum. The basic for independent t-test decision making is as follows:

a. If $t_{\text {value }}>t_{\text {table }}$, there are difference between emotional intelligence of students in control class and experiment class significantly.

b. If $t_{\text {value }}<t_{\text {table }}$, there are no difference between the emotional intelligence of students in control class and experiment clas s significantly.

\section{Results}

3.1 Feasibility of Project Based Learning Textbooks to Improve Students Emotional Intelligence

Feas ibility of textbooks to improve students emotional intelligence is doneby testing validation of products developed by competent experts on textbooks. This validation is needed to as sess the results of the first hypothesis testing based on validation of textbook by material experts, media experts, linguists and practitioners (Table 6).

Table 6. Recapitulation of Validation Test by Material Expert, Media Expert, Media

\begin{tabular}{ccc}
\multicolumn{2}{c}{ Linguist and Practitioner } \\
\hline No & Validator & Percentage \\
\hline 1 & Material Expert & $95 \%$ \\
\hline
\end{tabular}




\begin{tabular}{lcc}
\hline 2 & Media Expert & $97 \%$ \\
\hline 3 & Linguists & $90 \%$ \\
\hline 4 & Practitioner & $97 \%$ \\
\hline & Average & $\mathbf{9 5 \%}$ \\
\hline
\end{tabular}

Based on the recapitulation of the validation test, it shows that the percentage of the four components of validation is above $90 \%$. The highest percentage of validation results of media experts and educators was $97 \%$. The lowest percentag e of linguist validation tes ts was $90 \%$. The average percentage of the four components of validation was $95 \%$, and have category "very valid", "very thorough", and "feasible". So, it was concluded that textbooks appropriate to improve students emotional intelligence.

3.2 The Effectiveness of Project-Based Learning Textbooks to Improving Students Emotional Intelligence

3.2.1 Paired Sample t-test

Based on the results, which obtained some important data which are presented (Table 7).

Table 7. Recapitulation of Pretest and Posttest Data in Experiment Class and Control Class

\begin{tabular}{lccccccc}
\hline \multirow{2}{*}{ Class } & N & \multicolumn{2}{c}{ Mean } & \multicolumn{3}{c}{ Paired Sample T Test } \\
\cline { 3 - 7 } & & Pretest & Posttest & Mean T Count DF & $\begin{array}{c}\text { Sig. (2- } \\
\text { tailed) }\end{array}$ \\
\hline Experiment & 25 & 107,48 & 178,56 & -71.080 & -24.894 & 24 & 0,000 \\
\hline Control & 25 & 108,72 & 146,80 & -38.080 & -15.790 & 24 & 0,000 \\
\hline
\end{tabular}

The table above showed some important information. First, it shown that the value (2-tailed) in experiment class and control class are both 0.000 les s than 0.05 . It shows there was a difference between the pretestand posttests scores of students emotional intelligence in control clas s and the experiment clas s. Secondly, it can be known the $\mathrm{t}_{\text {value }}$ of experiment clas $s$ and control clas $\mathrm{s}$ is $-24,984$ and $-15,790 . \mathrm{T}_{\text {value }}$ of experiment class and control clas s indicate lower than mean posttest. So that in this context the negative value was positive, namely 24.984 and 15.790 . Both of these values were greater than the value of $t_{\text {table }}$ with $\mathrm{df} 24(\mathrm{a} / 2=0.05 / 2=0.025)$ which was 2.064. Similar to the significance value ( 2 tailed), this also shows differences in emotional intelligence of students before carrying out learning in experiment class and control class.

Third, there were the differences pretest and posttests score in experiment clas s and controlclass. were 107.48 and 178.56. Difference between the two classes was $-71,080$. While pretest and posttest score in control class were 108.72 and 146.80. The difference between the two from the mean paired differences is 38,080. The negative value of mean paired differences also shows the mean pretest which was lower than the mean posttest, so that in this context it was positive. To be clearer, a comparison of the pretest and posttests score in experiment clas s and control class could be seen in this histogram. 


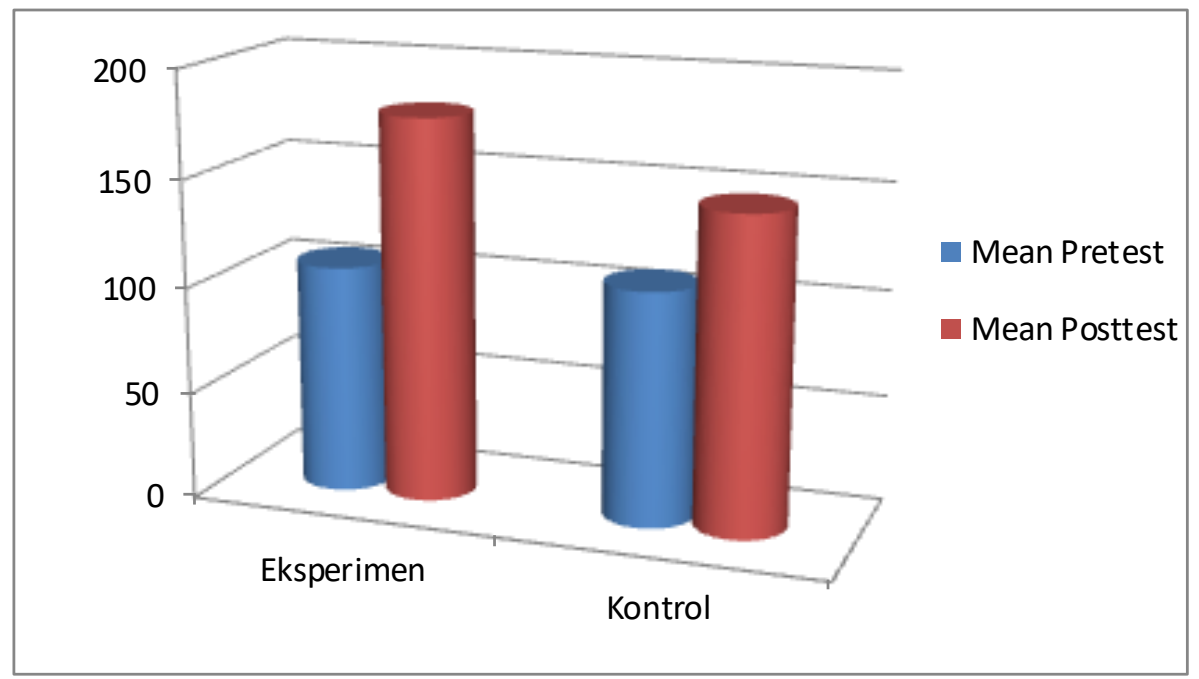

Fig 1. Comparis on Pretest and Posttest Score in Experiment and Control Class

Difference was the increasing pretestand posttests score of emotional intelligence in two classes, where increasing in emotional intelligence in experiment class was higher $(71,080)$ than control clas s $(38,080)$. So it can be said that both textbooks have an effect on increasing the emotional intelligence of students, but with different levels of effectiveness.

\subsubsection{Gain Analysis}

After getting emotional intelligence scores, then n-Gain analysis was performed. The test results are then interpreted according to the $n$-Gain interpretation category. The recapitulation of n-Gain test have shown at Table 8 .

Table 8. Recapitulation of N-Gain Test

\begin{tabular}{lcc}
\hline \multicolumn{1}{c}{ Class } & N-Gain Percentage & Interpretation \\
\hline Experiment & $63 \%$ & Medium \\
\hline Control & $34 \%$ & Low \\
\hline
\end{tabular}

In the table above, it shows that the percentage in experiment class was $63 \%$, it can be concluded that the use of project based learning textbooks in experiment clas s is effective enough to increase students emotional intelligence. Furthermore, it have shown that the percentage of n-Gain in control class was $34 \%$, interpretation concluded that the use of textbooks for students of class V revised 2017 issued by the government in the control class is less effective to improve students emotional intelligence. Based on the normalized n-Gain test, it was known that there are differences in the effectiveness of the use of project based learning textbooks developed by researchers and textbooks for students of the revised five grade 2017 
issued by the governmentto improve the emotional intelligence of students in the experimental and control classes.

\subsubsection{Independent sample test}

Independent sample test was results in Table 9.

Table 9. Recapitulation of Independent t-test Results

\begin{tabular}{|c|c|c|c|c|c|c|c|c|c|}
\hline \multicolumn{10}{|c|}{ Independent Samples Test } \\
\hline \multirow{3}{*}{$\begin{array}{l}\text { Emotional } \\
\text { Intelligence }\end{array}$} & \multicolumn{2}{|c|}{$\begin{array}{l}\text { Levene's Test } \\
\text { for Equality } \\
\text { of Variances }\end{array}$} & \multicolumn{7}{|c|}{ t-test for Equality of Means } \\
\hline & \multirow[t]{2}{*}{$\mathrm{F}$} & \multirow[t]{2}{*}{ Sig. } & \multirow[t]{2}{*}{$\mathrm{T}$} & \multirow[t]{2}{*}{ df } & \multirow[t]{2}{*}{$\begin{array}{c}\text { Sig. } \\
\text { (2-tailed) }\end{array}$} & \multirow[t]{2}{*}{$\begin{array}{c}\text { Mean } \\
\text { Difference }\end{array}$} & \multirow{2}{*}{$\begin{array}{c}\text { Std. } \\
\text { Error } \\
\text { Difference }\end{array}$} & \multicolumn{2}{|c|}{$\begin{array}{l}\text { 95\% Confidence } \\
\text { Interval of the } \\
\text { Difference }\end{array}$} \\
\hline & & & & & & & & Lower & Upper \\
\hline $\begin{array}{l}\text { Equal variances } \\
\text { assumed }\end{array}$ & .183 & .671 & $\begin{array}{c}8 . \\
790\end{array}$ & 48 & .000 & 28.95192 & 3.29391 & $\begin{array}{c}22 . \\
32906\end{array}$ & $\begin{array}{c}35 . \\
57478\end{array}$ \\
\hline $\begin{array}{l}\text { Equal variances } \\
\text { not assumed }\end{array}$ & & & $\begin{array}{c}8 . \\
790\end{array}$ & $\begin{array}{l}47 . \\
041\end{array}$ & .000 & 28.95192 & 3.29391 & $\begin{array}{c}22 . \\
32557\end{array}$ & $\begin{array}{c}35 . \\
57827\end{array}$ \\
\hline
\end{tabular}

Based on the testresults, it was known that the value of df (degree of freedom) is 48 , then the $t_{\text {table }}$ is 2.01063 . In addition it can also be seen that $t_{\text {value }}$ is 8.790 is greater than $\mathrm{t}_{\text {tahle }}(8.790>2.01063)$. So it can be concluded that there was a significant difference (real) between the use of textbooks based on project based learning to improve the emotional intelligence of students in experiment class with textbooks five grade 2017 revised government output used in control class.

\section{Discussion}

Research was motivated by emotional intelligence early on, as well as low emotional intelligence. The development research was conducted on five grade elementary school Rajabas a, Bandar Lampung. This research involves 50 students consisting of 25 at SD Negeri 1 Rajabasa as the control class and 25 students of SD Negeri 3 Rajabasa as an experiment class. The development research design used adapted the 9 stages of the research development of Borg \& Gall.

The feasibility of project based learning textbooks to improve students emotional intelligence was concluded based on expert validation tests, namely material experts, media experts, linguists and practitioners. After testing, it was known that the percentage of the expert was $95 \%$, validation test for media experts was $97 \%$, the validation test for linguists was $90 \%$, and the validation test for practitioners was $97 \%$. The average percentage of four components of validation was $95 \%$, have category "very valid", "very thorough" and "feasible". So, it was concluded that textbooks appropriate to improve students emotional intelligence. This is realized and has been proven in practice.

The textbooks for emotional intelligence is concluded based on 3 testing techniques, namely paired sample t-test, gain analysis and independent sample t-test. Pretest and posttest in experiment class was higher $(71,080)$ than control class $(38,080)$. The test results in experiment clas s have category "quite effective" $(63 \%)$, while the control class have category "less effective" (34\%). Independentt-test concluded difference use of project based learning 
textbooks in experiment clas s and the government revised 2017 five grade textbooks that used in control class.

Emotional intelligence possessed by someone can be said as a "driver" for every behavior displayed. Someone who has good emotional intelligence can put ones emotions in the right portion, sort out satisfaction and regulate mood. Mood coordination is the essence of good social relationships. If someone is good at adjusting to the mood of other individuals or can empathize, then it will be easier to adjust to social relations and the environment. Emotional intelligence related to individuals distinguish their emotions from the emotions of others. This ability is used to direct the mindset and behavior that will be dis played. Emotional intelligence is the result of the process of life's journey. Formed from psychological development, and related to the learning experience gained from the environment around the individual itself. This means emotional intelligence will be better if it seeks to be developed early, so that it can be strongly attached to each individual.

Emotional intelligence possessed by someone can be said as a "driver" for every behavior displayed. Research conducted by Maurice Elias, from Rutgers University to kindergarten students to grade 6 elementary school, children who participated in emotional intelligence development programs obtained results, namely more sensitive to other people feelings, better understand the consequences of their behavior, increased ability to "take advantage" of social situations, higher self-esteem, more concerned with the surrounding social conditions, made a place dependent by peers, better able to overcome the transition to secondary school, reduced anti-social nature, self-harm and inappropriate behavior in the socialenvironment, even after being tracked to public high school, increased skills to learn how to learn, increase self-control, social awareness, and social decision making inside and outside of school [3].

In addition, based on research conducted by Edobor \& Ebiye found that emotional intelligence can predict the decline in the tendency of secondary school students in Nigeria to engage in bullying and fighting [13]. On the other hand, Rivers et al. states that emotional intelligence is a protective factor againstrisky behavior in students, such as the use of illicit substances, alcohol, and fighting [14].

The results of research and development textbooks shows that emotional intelligence can be improved, one of them by using project based learning. This is in accordance with the opinion of Deveci and Nunn states the very nature of PjBL, allows students to use and increase their emotional intelligence. The experiental nature of PBL also engages students in communication with others providing them with the opportunities of debriefing and reapplication, which in turn supports the development of self-awareness and results in active participation as well as heightened motivation [7].

Based on research it is known that the use of textbooks based on project based learning helps students to improve their emotional intelligence, but it is still in the quite effective category. In addition, although it is not using textbooks based on project based learning in les sons still has the possibility of increasing the emotional intelligence of students. There are many causes, because emotional intelligence can be learned whenever and wherever learners are only effective will be different if the increase in emotional intelligence is considered and planned.

In addition, to the use of project based learning textbooks, there are other factors that influence the increase in students emotional intelligence. These factors can be from the family environment, non-family, physical or even psychological of each individual. Eisenberg \& Morris suggest that, several factors give the effect to childrens emotional intelligence [15]. Childs personality, neurophysiology and cognitive improvement skill important factors. In 
addition, Cole et al state, however that emotional intelligence can strengthen or weaken with social relations such as family and friends, but themost important is the family environtment [16]. This opens upopportunities for educators, parents and the community to be involved in increasing emotional intelligence in everyday life.

\section{Conclusion}

Results with the title "Development of Project Based Learning Textbooks To Improve Emotional Intelligence of Students in Five Grade in Elementary Schools", it can be concluded that the product in this research and development is entitled "Student Vocational School Elementary School Five Grade Based Project Based Learning Theme 1 Animal and Human Motion Organs Subtheme 4 Project and Literacy Based Activities". Assessment of values 95\%, media experts by $97 \%$, linguists $90 \%$ and practitioners by $97 \%$. Texbooks was developed was declared to be very valid, very complete and worthy of being used as a textbook aimed at increasing students' emotional intelligence. Project based learning textbooks could use in the learning process of students in class VA of SD Negeri 3 Rajabas a effectively to optimize students emotional intelligence. It proven by pretest and posttest score in experiment class are 107.48 and 178.56, the mean value of paired differences is -71.080 . While pretest and posttests score in control class are 108.72 and 146.80, the mean paired differences were -38.080. N-Gain in experiment class was 63\% (quite effective) while N-Gain in control class was 34\% (quite effective). Supported also testing value of 8.790 greater than $\mathrm{t}_{\text {table }}(8.790>2.01063)$.

\section{Acknowledgements}

Researchers would like to thank profusely to supervisors Rochmiy ati and Alben Ambarita to have giving suggestion and correction. Researcher als o give appreciation goes to five grade students of SDN 1 Rajabasa and SDN 3 Rajabasa, Indonesia and also to fellow teacher of Teachers of Elementary Teachers who also contributed in encouraging them to complete this research.

\section{References}

[1]Lamb, S., Maire, Q., \& Doecke, E.: Key Skills for the 21st Century an Evidence-Based Review. Centre for international research on education systems (Victoria University). Melbourne, Australia (2017)

[2]Given, B. K.: Brain-Based Teaching, Designing Teaching and Learning Activities Involving Emotional, Social, Cognitive, Kinesthetic Brain,and reflective. Mizan, Bandung (2013)

[3]Goleman, D.: Emotional Intelligence. Gramedia Pustaka Utama, Jakarta (2017)

[4]Mayer, John D \& Salovey, P.: The Intelligence of Emotional Intelligence. Department of Psychology. Yale University. New Haven, Connecticut. pp. 433-442 (1993)

[5]Berrocal, Pablo, F \& Checa.: Purificación. Emotional Intelligence and Cognitive Abilities. Frontiers in Psychology.ISSN 1664-8714 DOI.10.3389/978-2-88919-992-8 (2016)

[6]Serrat, O.: Understanding and Developing Emotional Intelligence. Asian Development Bank (www.adb.org). http://digitalcommons.ilr.cornell.edu/intl/189 (2009)

[7]Deveci, T \& Nunn, R.: Development in Freshman Engineering Students' Emotional Intelligence in Project-based Courses. The Asian ESP Journal.Vol.2. Pp. 54-92 (2016) 
[8]Gómez, M.: Project Based Learning. Valladoid university Spanyol. Pp. 9 (2016)

[9]Chiang, C. L. \& Lee, H.: The Effect of Project-Based Learning on Learning Motivation and Problem-Solving Ability of Vocational High School Students. International Journal of Information and Education Technology.Vol. 6, No. 9. Pp. 709-712 (2016)

[10]Tok, H.: TEFL Textbook Evaluation: from Teachers' Perspectives. Academic Journals.Vol. 5 (9), pp. 508-517 (2010).

[11]Gak, M.: Textbook - An Important Element In The Teaching Process. International Electronic Journal of Elementary Education.Vol. 9(2). Pp 69-82 (2011)

[12]Borg, W.R. \& Gall, M.D.: Educational Research an Introduction, Fifth Edition. New York.Longman (1983).

[13]Edobor, O.J., \&Ebiye, D.M.: Emotional Intelligence as Predictor of Delinquent Behaviours among Secondary School Students in Port Harcourt Metropolis, Rivers State Nigeria. European Journal of Research and Reflection in Educational Sciences.Vol.5(2). Pp.48-59 (2017)

[14]Rivers, S.E., Brackett, M.A., Omori, M., \& Sickler, C.: Emotion Skills as a Protective Factor for Risky Behaviors among College Students. Journal of College Student Development Vol. 54(2), 172-183 (2013)

[15]Eisenberg N, Spinrad TL, Morris AS.: Regulation, Resiliency and Quality of Social Functioning. Self and Identity Journal.Vol.1. Pp. 121-128 (2002)

[16]Cole PM, Martin SE, Dennis TA.:Emotion Regulation as a Scientific Construct: Methodological Challenges and Directions for Child Development Research. Child Development Journal.Vol.75. Pp. 317-333 (2004) 